\title{
Kebebasan dan Penodaan Agama: Menimbang Proyek “Jalan Tengah” Mahkamah Konstitusi RI
}

\author{
Rumadi \\ Dosen Fakultas Syariah dan Hukum UIN Syarif Hidayatullah Jakarta dan \\ Peneliti senior the WAHID Institute \\ arumadi@yahoo.com
}

\begin{abstract}
This article attempts to examine to waht extent the verdict of the Mahkamah Konstitusi on the judicial review about Law No. 1/PNPS/1965 on the eradication of blashphemy and defamation on religion has given perspective on the religious freedom and defamation of religion. It argues that the term 'penodaan agama' defined in the Indonesian Criminal Law is yague and has not clarified such relevant concepts as blashphemy, defamation of religion, and hatred speech. In fact, these three concepts are interchangeablely and chaotically used under this law. The author concludes that the Mahkamah Konstitusi has failed to take the 'middle way' so as to become a bridge and accommodate several interests retained in this legal attempt of judicial review and the Mahkamah Konstitusi takes not only constitutional but also political issues for its legal considerations, demonstrating that MK has obliviously revived the political ideology of 'Piagam Jakarta'.
\end{abstract}

\section{Abstrak}

Paper ini dimaksudkan untuk menguji sejauhmana Keputusan Mahkamah Konstitusi (MK) Republik Indonesia mempunyai perspektif mengenai kebebasan beragama dan penodaan agama dalam Amar Putusan terhadap judicial review UU No. 1/PNPS/1965 tentang Pencegahan Penyalahgunaan atau Penodaan Agama. Penulis berargumentasi bahwa penggunaan istilah penodaan agama dalam hukum pidana di Indonesia masih rancu dan belum dapat memilah beberapa konsep yang ada, seperti, blashphemy, defamation of religion, dan hatred speech. Nyatanya, ketiga konsep tersebut dipergunakan secara serampangan dan tumpang tindih. Di samping itu, penulis juga berkesimpulan bahwa MK telah gagal menempuh "jalan tengah" di anatara berbagai tarikan kepentingan dalam judicial review tersebut. Pertimbangan hukum MK tidak semata-mata soal konstitusi, tetapi juga memuat pertimbangan politik, di mana secara tidak disadari MK telah menghidupkan kembali ideologi politik "Piagam Jakarta". 
Kata Kunci: Mahkamah Konstitusi, kebebasan beragama, kasus penodaan agama, dan "jalan Tengah"

\section{Pendahuluan}

Mahkamah Konstitusi (MK) telah memutuskan masalah yang sangat penting dalam konteks kehidupan beragama di Indonesia, yaitu judicial review yang diajukan sejumlah kalangan, baik lembaga maupun individu, ${ }^{1}$ terhadap UU No. 1/PNPS/1965 tentang Pencegahan dan/atau Penodaan Agama (selanjutnya disebut UU Penodaan Agama). ${ }^{2}$ MK menolak seluruh permohonan yang diajukan pemohon agar UU tersebut dicabut. Pemohon berpendapat bahwa UU Penodaan Agama melanggar prinsip-prinsip kebebasan beragama yang dijamin secara tegas dalam konstitusi, UUD 1945.

Dalam teori kebebasan beragama dikenal dua istilah yang biasanya digunakan untuk membedakan wilayah yang bisa diintervensi dan wilayah yang tidak bisa diintervensi (derogable and non-derogable rights). Semangat dari pembedaan ini juga dicantumkan dalam pasal 18 International Covenant on Civil and Political Rights (ICCPR), yang sudah diratifikasi pemerintahan Indonesia melalui UU No. 12 Tahun 2005. Dalam kaitan itu dibedakan dua wilayah kebebasan beragama yaitu wilayah forum internum yang bersifat mutlak dan tidak bisa diintervensi apalagi dikriminalisasi (non derogable rights); ada wilayah forum externum yang bisa diatur dan dibatasi dan diatur karena terkait dengan ekspresi dari keyakinan keagamaan (derogable rights). Hak beragama dan memeluk sebuah keyakinan merupakan hak yang tidak bisa dikurangi dalam kondisi apapun. MK sebenarnya menyebut konsep tersebut, namun tidak digunakan secara konsisten.

Dalam Amar Putusan No. 140/PUU-VII/2009, MK menyatakan bahwa UU Penodaan Agama, meski dibuat dalam situasi darurat pada 1965, masih dianggap relevan, tidak bertentangan dengan UUD 1945 terutama yang terkait dengan Hak Asasi Manusia (HAM) dan kebebasan beragama dan berkeyakinan. Alih-alih mencabut, MK justru berkeyakinan, jika UU Penodaan Agama dicabut, akan muncul anarki dan kekacauan sosial karena akan terjadi

\footnotetext{
${ }^{1}$ Permohonan judicial review dilakukan oleh sejumlah Lembaga Swadaya Masyarakat yang bergerak dalam isu kebebasan beragama dan HAM, antara lain Perkumpulan Inisiatif Masyarakat Partisipatif untuk Transisi Berkeadilan (Imparsial), Lembaga Studi dan Advokasi Masyarakat (Elsam), Perhimpunan Bantuan Hukum dan Hak Asasi Manusia (PBHI), Perkumpulan Masyarakat Setara (Setara Institute), Yayasan Desantara, Yayasan Lembaga Bantuan Hukum Indonesia (YLBHI). Di samping lembaga, permohonan juga diajukan sejumlah individu, yaitu: KH. Abdurrahman Wahid (akhirnya dianggap gugur karena meninggal dunia sebelum proses persidangan selesai), Siti Musdah Mulia, M. Dawam Raharjo dan Maman Imanul Haq.

${ }^{2}$ Pengucapan dan pembacaan put usan; MK dilakukan pada 19 April 2009.
} 
kekosongan hukum. UU Penodaan Agama dianggap tidak terkait dengan kebebasan beragama, tapi hanya terkait dengan penodaan agama.

MK berpendapat bahwa untuk kepentingan perlindungan umum (general protection) dan antisipasi terjadinya konflik di tengah-tengah masyarakat baik horizontal maupun vertikal, maka adanya UU Penodaan Agama dinilai sangat penting. MK berpendapat bahwa pada hakikatnya ide pengujian konstitusionalitas oleh pemohon adalah untuk mencari tafsir kebebasan beragama di Indonesia dan bagaimana bentuk pencegahan atas penodaan terhadap agama. Selain itu, pengujian UU ini secara substansi juga dimaksudkan untuk melihat sejauhmana relevansi UU Penodaan Agama apabila dikontekskan dengan kondisi sosial masyarakat saat ini.

Dalam pertimbangannya, MK menilai bahwa UU Penodaan Agama masih tetap sah secara formil, memberikan kepastian setiap orang dilarang dengan sengaja menyebarkan dan menganjurkan untuk melakukan penafsiran terhadap kegiatan yang menyimpang dari pokok agama. Undang-undang ini masih diperlukan dan tidak melanggar HAM, bahkan bisa mencegah tindakan anarki. Sedangkan terhadap kepentingan masyarakat penganut kepercayaan yang sudah lama hidup di Indonesia, MK berpendapat, masyarakat penganut kepercayaan adalah masyarakat yang memiliki hak dan kewajiban yang sama dalam meyakini kepercayaannya sesuai dengan jaminan dalam UUD 1945. Praktik diskriminasi yang dialami oleh masyarakat penganut kepercayaan adalah bentuk dari kesalahan penerapan norma dalam hukum administrasi dan bukan merupakan permasalahan pertentangan norma UU Pencegahan Penodaan Agama terhadap UUD 1945.

Dasar pertimbangan yang dijadikan argumen MK untuk mengambil keputusan ini tidak semata terkait dengan konstitusi, tapi juga ada pertimbangan sosiologis-politis. Pertimbangan sosiologis antara lain tampak dalam argumen MK yang menyatakan bahwa jika UU ini dicabut maka akan terjadi kekacauan, keresahan, perpecahan, dan permusuhan masyarakat karena adanya kekosongan hukum (h. 287). Alih-alih melanggar konstitusi, UU Penodaan Agama justru dilihat sebagai upaya untuk melindungi dan menjaga ketentraman kehidupan beragama.

Pertimbangan politis disini terkait dengan relasi agama dan Negara. Anehnya, MK mengutip Majalah Media Dakwah No. 258/Desember 1995 untuk menjelaskan Surat Keputusan Bersama (SKB) Menteri Agama dan Menteri Pendidikan, Pengajaran dan Kebudayaan yang mewajibkan sekolah umum memberi pelajaran agama kepada anak didiknya; serta mengutip Majalah Suara Hidayatullah No. 02/IX/Juni 1996 untuk menjelaskan larangan pemerintah Amerika Serikat melarang mengajarkan agama di sekolah-sekolah negeri. Kutipan dari dua majalah tersebut, bagi penulis, agak aneh karena kita 
tahu haluan Islam seperti apa yang dianut kedua majalah tersebut. Apakah dengan demikian, paham MK mengikuti paham politik-keagamaan dua majalah tersebut?. Di sini MK mengambil mazhab pemikiran bahwa dengan sila "Ketuhanan Yang Maha Esa", negara diperbolehkan untuk melakukan berbagai hal, termasuk mengintervensi keyakinan keagamaan warganya jika dianggap keyakinannya tidak berketuhanan yang maha Esa.

Karena itu, pada tingkat tertentu, putusan MK ini memberi jalan legal bagi negara untuk melakukan intervensi terhadap kehidupan umat beragama. Bidang apa yang bisa diintervensi? Dalam hal ini MK absen memberi koridor. Meski dalam putusan itu disebut-sebut kategori forum internum dan forum externum, namun hal tersebut nyaris tidak menjadi rujukan argumen. Karena itu, bisa ditafsirkan, putusan ini memberi jalan interyensi negera terhadap agama, bukan saja terkait dengan forum externum, tapi bisa juga forum internum. Kata kuncinya adalah pasal 28J UUD 1945, yang membatasi hak asasi manusia, termasuk kebebasan beragama, melalui pertimbangan moral, nilai-nilai agama, keamanan dan ketertiban umum. Pembatasan tersebut tidak hanya terkait dengan ekspresi keberagamaan (forum externum), tapi juga forum internum. Putusan MK justru mengaburkan hal ini.

Memang, di bagian akhir keputusan MK tersirat persetujuan untuk melakukan revisi terhadap UU Penodaan Agama, baik menyangkut lingkup formil perundang-undangan maupun secara substansi agar memiliki unsur-unsur materiil yang lebih jelas sehingga menimbulkan salah tafsir dalam pratik. Secara tidak langsung sebenarnya MK juga mengakui adanya salah tafsir dan kesewenang-wenangan dalam praktik. Namun hal ini tidak cukup dijadikan alasan bahwa UU ini inskonstitusional. Kesewenang-wenangan dalam penerapan sebuah norma dalam perundang-undangan, semata terkait dengan pertimbangan hakim dalam berbagai kasus yang dihadapi. Sayangnya, dalam putusan tersebut tidak ada dorongan kuat dari MK kepada DPR untuk melakukan revisi. Dengan berlindung dibalik kewenangannya sebagai negative legislator, MK hanya memberi pernyataan datar, bahwa untuk memperbaiki agar UU ini lebih sempurna menjadi kewenangan pembentuk undang-undang (pen. DPR) melalui proses legislasi yang normal. ${ }^{3}$

\footnotetext{
${ }^{3}$ Memang benar bahwa MK hanya memiliki kewenangan sebagai negative legislator, dan MK tidak bisa membuat norma hukum baru dalam melakukan uji material sebuah UU. Apa yang dilakukan MK terkait dengan uji materiil UU Penodaan Agama merupakan tafsir konservatif terhadap negative legislator. Dalam kasus yang UU Pemilu dimana MK bisa membuat norma hukum baru dengan memperbolehkan KTP sebagai bukti kebolehan melakukan pencoblosan dalam pemilu 2009 lalu merupakan tafsir progresif at as negative legislator. Kasus lain yang menarik untuk diperbandingkan adalah deadline MK kepada DPR agar badan legislatif itu segera membuat UU Pengadilan Tindak Pidana Korupsi sampai batas waktu tertentu. Dari sini bisa dilihat, kadangkadang MK bisa secara progresif menafsirkan hak negative legislator dan itu dilakukan beberapa
} 
Dalam tulisan ini, penulis tidak ingin terjebak dengan perdebatan hukum dan pasal-pasal perundang-undangan yang memang bukan kapasitas penulis. Penulis juga tidak memberi penilaian apakah argumen konstitusional MK tepat atau tidak, namun penulis akan meletakkan putusan MK ini dalam konteks yang lebih luas terkait dengan regulasi agama dan kehidupan beragama. Dari sini diharapkan akan tampak bahwa UU Penodaan Agama tidak bisa dilepaskan dari persoalan hak asasi manusia dan kebebasan beragama. Karena itu, jika dikatakan bahwa UU Penodaan Agama tidak ada kaitan dengan kebebasan agama sebagaimana dikatakan saksi ahli, KH. Hasyim Muzadi, tidaklah tepat. Meskipun UU yang direview adalah UU Penodaaan Agama, perbincangan persoalan ini tidak bisa dilepaskan dari persoalan kebebasan beragama.

\section{Blasphemy, Defamation of Religion dan Hatred Speech}

Sebelum mendiskusikan lebih jauh putusan $\mathrm{MK}$, penulis merasa perlu untuk menguraikan tiga konsep yang sangat penting, tapi dalam amar putusan MK tidak dibahas secara memadai. MK hanya menyebut istilah penodaan agama untuk merangkum tiga konsep tersebut, padahal tekanan dan konsekuensi ketiganya berbeda. Ketiga konsep tersebut agak sulit dibedakan dengan Bahasa Indonesia, namun untuk membedakan penulis akan menyebut blasphemy dengan penodaan agama, defamation of religion dengan penistaan agama dan hatred speech dengan pernyataan kebencian.

Secara teoritik, delik agama bisa dibagi dalam beberapa kategori: pertama, religionsschutz-theorie (teori perlindungan agama). Menurut teori ini, agama itu sendiri dilihat sebagai kepentingan hukum atau obyek yang akan dilindungi atau dipandang perlu dilindungi oleh negara melalui peraturanperaturan yang dibuat. Kedua, gefuhlsshutz-theorie (teori perlindungan perasaan keagamaan). Menurut teori ini, kepentingan hukum yang akan dilindungi adalah rasa/perasaan keagamaan orang-orang yang beragama. Ketiga, friedensschutz-theorie (teori perlindungan perdamaian/ketenteraman umat beragama). Obyek atau kepentingan hukum yang dilindungi menurut teori ini adalah kedamaian/ketenteraman beragama interkonfensional (di antara pemeluk agama/kepercayaan). Dengan demikian, perlindungan lebih ditujukan pada ketertiban umum. ${ }^{4}$

kali dalam putusan hukumnya. Sayangnya, dalam UU Penodaan Agama MK memilih langkah konservatif.

${ }^{4}$ Lihat Oemar Senoadji, Hukum (Acara) Pidana dalam Prospeksi (Jakarta: Erlangga, 1976), 75. Teori ini dikutip ulang oleh Barda Nawawi Arief, Delik Agama dan Penghinaan Tuhan (Blasphemy) di Indonesia dan Perbandingan Berbagai Negara (Semarang: UNDIP Semarang, 2007), 2. 
Dari teori tersebut, Barda Nawawi Arief kemudian merumuskan bahwa istilah tindak pidana atau delik agama dapat diartikan: 1) tindak pidana/delik "menurut agama". Delik ini mencakup perbuatan-perbuatan yang menurut hukum yang berlaku merupakan tindak pidana dan dilihat dari sudut pandang agama juga merupakan perbuatan terlarang atau tercela. Hal ini mencakup juga perbuatan yang menurut hukum yang berlaku tidak dianggap sebagai tindak pidana, tapi dari sudut pandang agama dipandang sebagai perbuatan pidana; 2) Tindak pidana/delik "terhadap agama". Delik ini terkait dengan perbuatanperbuatan yang dianggap menghina atau menistakan terhadap agama atau halhal yang disakralkan oleh agama. Dengan demikian, delik ini dimaksudkan untuk melindungi agama dari perbuatan-perbuatan yang menghinakan Tuhan dan agama. Perbuatan-perbuatan itulah yang dipandang sebagai blasphemy atau Godslastering (penghinaan terhadap Tuhan). 3) Tindak pidana/delik "yang berhubungan dengan agama" atau "terhadap kehidupan beragama". Delik ini terkait dengan perbuatan-perbuatan yang sebenarnya tidak terkait langsung dengan agama, tapi menyangkut kehidupan keagamaan masyarakat, seperti merintangi pertemuan atau upacara keagamaan, penguburan jenazah, menghina benda-benda yang digunakan untuk ibadah, mengganggu orang yang sedang beribadah. $^{5}$

Dalam hukum pidana di Indonesia, delik jenis pertama cukup banyak dalam KUHP, seperti larangan pembunuhan, pencurian dan sebagainya, meskipun tidak semua perbuatan yang dianggap sebagai kejahatan oleh agama dimasukkan sebagai kejahatan pula oleh KUHP. Pindah agama (murtad) misalnya, meskipun oleh Islam dianggap sebagai tindak pidana, namun KUHP tidak menjadikan pindah agama sebagai kejahatan. Delik yang banyak diakomodasi dalam KUHP justru delik ketiga, yaitu delik yang terkait dengan kehidupan keagamaan masyarakat. Sedang delik jenis ke-2, delik terhadap agama, pada awalnya tidak dikenal dalam KUHP. Delik terhadap agama baru dimasukkan dalam KUHP melalui UU No. 1/PNPS/1965 yang menjadi bahasan utama dalam tulisan ini.

\section{Blasphemy}

Blasphemy berasal dari blasphemein (Yunani kuno), blasphemen, (istilah Inggris zaman pertengahan), blafemer (istilah Perancis kuno), blasphemare (Latin), yang merupakan paduan dari kata blaptein (merusak) dan pheme (reputasi). Blasphemy juga bisa diartikan sebagai defamation of the name of God, yang berarti penistaan nama Tuhan. Dalam arti luas, blasphemy dapat diartikan sebagai penghujatan terhadap hal-hal yang dianggap suci oleh

${ }^{5}$ Barda Nawawi Arief, Delik Agama, 1. 
suatu keyakinan agama. Bentuk blasphemy umumnya adalah perkataan atau tulisan yang menentang ketuhanan terhadap agama-agama yang mapan.

Dalam tradisi agama-agama Abraham (Yahudi, Kristen dan Islam) dikenal berbagai bentuk larangan blasphemy. Dalam Yahudi, blasphemy adalah menghina nama Tuhan atau mengucapkan hal-hal yang mengandung kebencian terhadap Tuhan. Dalam Kristen, Kitab Perjanjian Baru, dikatakan menista roh kudus adalah dosa yang tak diampuni dan pengingkaran terhadap Trinitas juga digolongkan sebagai blasphemy. Dalam Kitab perjanjian lama, pelaku blasphemy diancam hukuman mati, dengan cara dilempari batu. Dalam Islam, blasphemy adalah menghina Tuhan, Nabi Muhammad dan nabi-nabi yang diakui dalam al-Qur' an serta menghina al-Qur'an itu sendiri. Budha dan Hindu tak mengenal adanya blasphemy, paling tidak secara resmi.

Blasphemy menjadi hukum negara sejak munculnya teokrasi, dimana terjadi penyatuan antara kekuasaan agama degan kekuasaan politik. Negaranegara Eropa pada abad Ke-17 menetapkan pelaku penistaan agama sebagai tindak kejahatan yang dapat dijatuhi hukuman berat. Di wilayah lain juga terjadi penyatuan antara agama dan politik, baik itu negara Kristen, Yahudi maupun Islam. Tujuan memidanakan penistaan agama adalah untuk membatasi kebebasan berbicara tidak melanggar norma sosial mengenai kesopanan dan hak orang lain.

Di Eropa Abad Ke-17, karena Kristen merupakan jantung hukum Inggris, maka hukum dibuat berdasarkan nilai-nilai Kristen. Setiap perkataan yang bertentangan dengan nilai dan ajaran Kristen dianggap sebagai tindak pidana. Tentu saja, hukum mencerminkan nilai dan pandangan agama dominan saat itu, dan mengabaikan pandangan keyakinan minoritas. ${ }^{7}$

Pada abad ke-20, penistaan agama pelan-pelan dihapus dari hukum pidana di beberapa negara Eropa. Di Inggris, akar hukum penistaan agama muncul 1938, hanya berlaku untuk penistaan terhadap Gereja Anglikan, tidak berlaku untuk penghinaan agama Yahudi, Islam, bahkan Kristen non-Anglikan. Tujuan pemidanaan ini adalah untuk mempertahankan supremasi gereja Anglikan. Kasus penistaan agama terakhir terjadi pada abad-19. Mulai abad-20, praktek pemidanaan penistaan agama sudah hilang, kendatipun pasal pidananya tak pernah dihapus. Penistaan agama kemudian bergeser dari pidana menjadi masalah hukum perdata, namun sangat jarang. Sepanjang abad-20, hanya ada 4 kasus perdata terhadap perbuatan penghujatan agama. Kasus terakhir terjadi

\footnotetext{
${ }^{6}$ Carly Carlberg, 'Freedom of Expression in Modern Age: An Obscure Blasphemy Statute and Its Effect on Bussiness Naming, "Rutger Journal of Law and Religion," Volume II (Fall 2009), Part I.

${ }^{7}$ Carly Carlberg, "Freedom of Expression in Modern Age: An Obscure Blasphemy Stat ute and Its Effect on Bussiness Naming.” Lihat juga Barda Nawawi Arif, Delik Agama, 65-86.
} 
tahun 1979 antara Whitehouse versus Lemon. Kasus itu bermula dari penerbitan puisi di majalah Gay News, yang menggambarkan Yesus Kristus sebagai homoseksual. Penerbit majalah tersebut didenda 500 pound dan hukuman percobaan 9 bulan. Majalahnya didenda 1000 pound dan harus membayar pengganti penjara 10.000 pound. Kasus Salman Rusdhie yang digugat di Inggris tidak berujung pada penghukuman.

Seperti Inggris, di Australia yang merupakan bekas jajahan Inggris, blasphemy juga hanya berlaku terhadap tindakan penghinaan gereja Anglikan, walau tak seperti Inggris, Australia tak memiliki agama resmi. Kendati banyak undang-undang, baik federal, negara bagian, maupun hukum kebiasaan yang memidanakan penistaan agama, hal ini jarang terjadi di Australia. Pemidanaan agama terakhir di negeri Kanguru itu terjadi tahun 1971, dalam kasus Wiliam Lorando Jones. Jones didakwa menista gereja Anglikan di negara bagian New South Wales karena berbicara di depan umum bahwa Perjanjian Lama itu immoral dan tak cocok bagi perempuan. Jones dihukum denda 100 pound dan penjara 2 tahun. Setelah kasus itu, tahun 1871, parlemen New South Wales mengusulkan UU Opini Mengenai Agama, yang intinya menghentikan pemidanaan terhadap penistaan agama. Ibukota Australia lalu mengadopsi UU tersebut pada 1996, menghapuskan pemidanaan penistaan agama melalui reformasi hukum.

Pemidanaan penistaan agama di Jerman diatur dalam bab 11 "KUHP" Jerman. Penistaan agama didefinisikan sebagai tindakan penghinaan terhadap ajaran lain at au pandangan hidup yang berakibat pada ketidaktertiban; "barang siapa yang menyebarkan tulisan yang menghina ajaran agam lain atau ajaran mengenai pandangan hidup dengan cara yang dapat menyebabkan gangguan terhadap ketertiban umum". Jika seseorang melakukan tersebut, ia diancam pidana penjara paling lama tiga tahun atau denda. Sebagai bentuk aplikasi dari aturan ini, pada Februari 2006, aktivis politik Jeran Manfred van H, dijatuhi hukuman satu tahun percobaan dan hukuman kerja sosial selama 300 jam karena menyebarkan tisu toilet yang dicetak ayat-ayat al-Qur'an dan dibagibagikan ke masjid dan media-media.

AS juga mengenal blasphemy meski banyak pendiri AS adalah orangorang yang melarikan diri dari hukuman penistaan agama di negara asalnya di Eropa. AS memiliki hukuman pidana yang keras terhadap penghujat agama. Di beberapa negara bagian AS, penghujatan agama dapat dihukum mati. Namun demikian, sejak desakan amandemen pertama konstitusi AS, pemidanaan terhadap penistaan dilarang karena bertentangan dengan kebebasan berekspresi.

Di Asia, Pakistan merupakan negara di dunia yang paling keras mengancam penistaan agama. Menurut "KUHP" Pakistan, "barangsiapa dengan kata-kata, baik lisan maupun tertulis, gambar, tuduhan, gaung, atau insinuasi, 
baik langsung maupun tak langsung, yang mencemarkan nama suci Nabi Muhammad, diancam hukuman mati, atau penjara seumur hidup, dan juga diancam denda." Tahun 2000, seorang guru bernama Muhammad Younas Seikh, menjelaskan di kelas bahwa sebelum Nabi Muhammad menerima wahyu al-Qur'an belum masuk Islam, dijerat dengan penistaan agama dan dihukum mati. Dalam 10 tahun terakhir, 12 orang dieksekusi mati dengan tuduhan penistaan agama, 560 orang didakwa menista agama di pengadilan, dan 30 orang masih menungguh vonis. ${ }^{8}$

\section{Defamation of Religion dan Batasan Kebebasan Berekspresi}

Sejak 1999, masalah Defamation of Religion (penistaan agama) menjadi perhatian PBB. Beberapa kali Sidang Umum PBB menerbitkan resolusi tidak mengikat yang mengecam "penghinaan terhadap agama" (defamation of religion). Resolusi tersebut disponsori oleh Pakistan atas nama OKI, dan Mesir atas nama Afrika, dalam Durban Conference, sebagai upaya untuk menghentikan polarisasi, diskriminasi, ekstrimisme dan misintepretasi terhadap Islam. Hal ini merupakan respon terhadap perkembangan pasca perisitiwa "11 September" dimana Islam sering dinistakan dan senantiasa dikaitkan dengan terorisme dan pelanggaran HAM.

Namun demikian, dalam Konferensi Durban review II di Jenewa, resolusiresolusi mengenai "defamation of religion" dinilai bertentangan dengan hak asasi manusia, karena terlalu sempit pada perlindungan Islam (awal mula draftnya berjudul "defamation of Islam"), konsep tersebut melindungi agama (yang esensinya adalah idiologi) bukannya melindungi hak individu, terlalu mempertentangkan agama, mengancam hak atas kebebasan berekspresi, ditulis dengan bahasa yang terlalu umum dan tidak jelas, termasuk dalam penggunaan istilah "penistaan" (defamation). ${ }^{9}$ Berdasarkan evalusi yang disampaikan oleh beberapa pelapor khusus PBB, penerapan konsep "defamation of religion" di beberapa negara, seperti Pakistan, Iran dan Mesir, justru menimbulkan masalah hak asasi manusia, seperti pembungkaman kebebasan berekspresi, xenophobia dan ketegangan antar umat beragama. Sehingga, konsep "defamation of religion" kembali dipertanyakan. ${ }^{10}$

Sebagi solusi, muncullah upaya-upaya untuk membuat instrumen hak asasi manusia internasional untuk menyeimbangkan antara hak atas kebebasan

\footnotetext{
${ }^{8}$ Brinton Priestly, Blasphemy and Law: A Comparative Study (2006), http://www.brentonpriestley.com/writing/blasphemy.htm.

${ }^{9}$ Becket Found for Religious liberty Issues Brief, “Defamation of Religion”, July 2008 (Versi Publikasi).

${ }^{10}$ Akhirnya, resolusi Dewan HAM PBB mengenai “Defamation of Religion” dicabut pada sidang Dewan HAM 2009.
} 
berekspresi namun tetap menjamin perdamaian, terutama antara umat beragama. Komisi mengembangkan sebuah inisiatif dengan mengeluarkan sebuah resolusi untuk mengatasi ketegangan antara kebebasan berekspresi dan perdamaian antara umat beragama dan ras. Bagaimana pembatasan kebebasan berekspresi tetap berdasarkan DUHAM dan International Covenant on Civil and Political Rights (ICCPR).

Kebebasan berekspresi sendiri dapat dibatasi, sesuai pasal 20 Kovenan Hak-Hak Sipil dan Politik, yaitu:

1) Any propaganda for war shall be prohibited by law.

2) Any advocacy of national, racial or religious hatred that constitutes incitement to discrimination, hostility or violence shall be prohibited by law.

Selain itu, pasal 19 ICCPR mengatan bahwa kebebasan berekspresi dapat dibatasi "to protect among others, the rights of others, public order, and national security if it is "necessary in a democratic society" to do so and it is done by law." Namun tidaklah mudah membuat rumusan praktis pembatasan kebebasan berekspresi berdasarkan ICCPR dan instrumen HAM internasional lain. Dewan HAM Eropa menetapkan syarat-syarat pembatasan kebebasan berekspresi harus lolos tiga syarat sebagai berikut:

1. Pembatasan dibuat untuk tujuan yang benar-benar sah;

2. Pembatasan harus dilakukan dalam kerangka demokratis (jadi harus oleh parlemen atau lembaga yang diberi kekuasaan oleh parlemen);

3. Pembatasan harus benar-benar merupakan keniscayaan (necessity) bagi masyarakat demokratis. Jadi kata necessity tidak hanya sekedar "berguna" (useful) dan "beralasan" (reasonable). ${ }^{11}$

Menurut Dewan HAM Eropa, ada kebutuhan untuk membuat hukum anti penistaan agama di Eropa. Namun penilaian Dewan HAM Eropa tersebut dikritik oleh Article XIX, dengan alasan tidak ada kepastian hukum penistaan agama, dengan pertimbangan:

1. Tidak ada nesesitas untuk hukum penistaan agama, karena "public good" akan lebih baik disampaikan melalui perdebatan dari berbagai sisi, sekalipun dengan istilah yang keras dan ofensif masih lebih bagus;

2. Tidak ada bukti nyata bahwa kebebasan berekspresi dan kebebasan beragama akan berjalan lebih baik dengan adanya hukum anti penistaan agama. Harus ditegaskan bahwa kebebasan beragama bukan

\footnotetext{
${ }^{11}$ Article XIX, Freedom of Expression and Offense, presentasi oleh Sarac Richani.
} 
berarti untuk menghormati agama, tapi adalah menghormati hak setiap orang untuk beragam dan beribadah menurut keyakinannya;

3. Kebebasan berekspresi bukan hanya untuk ide dan informasi yang "harmonis" tapi juga untuk ide yang mengagetkan, keras, dan juga mengganggu;

4. Penerapan hukum penistaan di berbagai tempat di dunia adalah justru untuk membatasi kemerdekaan orang untuk beragama, dan umumnya korbannya adalah penganut agama-agama minoritas. ${ }^{12}$

Dengan demikian, penebar kebencian (hate speech) adalah yang sah (legitimed) untuk membatasi kebebasan berekspresi. Perlindungan hak asasi manusia harus didasarkan prinsip persamaan martabat dan kesetaraan setiap orang, tanpa membedakan suku, ras, jenis kelamin, kebangsaan dan agama. Pernyataan kebencian merupakan ancaman terhadap martabat manusia dan menciptakan kondisi yang tidak memungkinkan adanya kesetaraan antara manusia. Untuk itu, pelarangan pernyataan kebencian merupakan nesesitas untuk menghindari permusuhan, deskriminasi dan kekerasan antara ras, suku, bangsa, agama dan jenis kelamin. ${ }^{13}$

\section{Kasus Penodaan Agama sebagai Proyek "Jalan Tengah" Mahkamah Konstitusi}

Salah satu poin penting yang layak untuk mendapat perhatian adalah keinginan MK untuk membangun proyek "jalan tengah". Hal ini tercermin dalam kutipan berikut:

"Adapun pendapat Mahkamah atas pandangan Jalaluddin Rahmat yang menyarankan agar Mahkamah membuat "jalan tengah" dengan memberi penafsiran resmi atas UU Pencegahan Penodaan Agama tanpa membatalkannya, Mahkamah sependapat dengan pandangan tersebut. Hal itu telah dilakukan oleh Mahkamah. Penafsiran Mahkamah tentang segi-segi tertentu atas UU Pencegahan Penodaan Agama telah dituangkan secara rinci dalam paragraf-paragraf di bagian Pendapat Mahkamah di atas yang kesemuanya dapat dipandang sebagai "jalan tengah" sebagaimana diusulkan oleh Ahli Jalaluddin Rahmat". 14

Pertanyaannya, apa yang dimaksud proyek "jalan tengah" dalam keputusan mengenai UU Penodaan Agama? Dalam kaitan ini kita bisa

\footnotetext{
${ }^{12}$ Article XIX, Freedom of Expression and Offense.

${ }^{13}$ Article XIX, Freedom of Expression and Offense.

${ }^{14}$ Amar Putusan MK No. 140/PUU-VII/2009, 263.
} 
menelusuri fakta pengadilan bagaimana yang mendorong MK mengambil posisi tersebut. Setidaknya ada dua saksi yang menyebut istilah "jalan tengah", yaitu Jalaluddin Rahmat dan Yusril Ihza Mahendra. Jalaluddin mengusulkan jalan tengah, yaitu Mahkamah mempertahankan UU Pencegahan Penodaan Agama sekaligus mengakomodasi kepentingan pihak yang merasa dirugikan. Sedang Yusril meletakkan konsep jalan tengah dalam konteks pertarungan ideologis negara Islam versus negara sekuler. Menurut Yusril, negara Indonesia tidak merdeka sebagai sebuah negara Islam dan negara sekuler, akan tetapi mengambil jalan tengah yaitu negara berdasarkan ketuhanan dengan kewajiban menjalankan syariat Islam bagi pemeluk-pemeluknya menurut dasar kemanusiaan yang adil dan beradab. Walaupun kalimat kompromi ini dihapus, namun semangat keagamaan dalam penyelenggaraan kehidupan bermasyarakat, berbangsa, dan bernegara tidak pernah lenyap untuk selama-lamanya.

Berdasarkan paparan di atas, proyek "jalan tengah" yang dimaksud di sini menyangkut dua hal, yaitu menengahi tuntutan para pihak untuk mencabut UU Penodaan Agama di satu sisi, dan tuntutan untuk mempertahankan sepenuhnya di sisi yang lain. Sedang "jalan tengah" yang kedua adalah menengahi pertarungan ideologis "negara Islam" versus "negara sekuler". Dengan demikian, proyek "jalan tengah" MK melalui penegasan kembali delik penodaan agama harus diletakkan dalam kerangka tersebut, di mana MK menegaskan seluruh pendapat Mahkamah dalam putusan judicial review ini merupakan "jalan tengah" itu sendiri. Pertanyaannya, benarkah seluruh pendapat Mahkamah dalam konteks UU Penodaan Agama merupakan "jalan tengah?’ Inilah pertanyaan kunci yang ingin diuji dalam bagian ini.

\section{"Jalan Tengah": Antara Dicabut atau Dipertahankan}

Penulis tidak sepenuhnya bisa melihat bahwa keputusan MK ini merupakan jalan tengah sebagaimana diuraikan di atas. Marilah kita lihat hal ini secara hati-hati. Sebelum membuat putusan, MK memetakan adanya tiga kelompok pandangan menyikapi UU Penodaan Agama yang terekam dalam proses persidangan. Pertama, kelompok yang menyatakan UU Penodaan Agama konstitusional dan menghendaki dipertahankan eksistensinya secara apa adanya, tanpa perubahan dan revisi. Kedua, kelompok yang menyatakan UU Penodaan Agama konstitusional tetapi menghendaki dilakukan revisi karena beberapa bagiannya dipandang bermasalah. Ketiga, kelompok yang menyatakan UU Penodaan Agama inkonstitusional dan kerenanya harus dibatalkan dan dicabut. Melihat tiga kelompok tersebut, secara jelas bisa dilihat bahwa "jalan tengah" itu adalah kelompok kedua. Kalau memang MK melakukan "jalan tengah" seharusnya putusannya lebih condong ke kelompok kedua. 
Sayangnya, putusan MK lebih mengafirmasi cara pandang kelompok pertama daripada kelompok kedua, apalagi kelompok ketiga. ${ }^{15}$ Sebenarnya, ada upaya MK untuk masuk ke posisi kedua, namun hal itu tidak tampak tegas dilakukan, misalnya dengan menunjukkan aspek-aspek problematik dalam UU Pencegahan Penodaan Agama sebagaimana disampaikan sejumlah ahli dan mendorong DPR melakukan langkah-langkah untuk merevisi UU tersebut. Namun, sekali lagi, tidak ada isyarat yang jelas dari MK mengenai hal ini. Dalam kaitan ini, dalam bagian "menimbang", MK hanya menyatakan persetujuannya dengan pendapat para ahli seperti Andi Hamzah, Azyumardi Azra, Edy OS Hiariej, Emha Ainun Nadjib, Siti Zuhro, Jalaluddin Rakhmat, Ahmad Fedyani Saefuddin, Taufik Ismail dan Yusril Ihza Mahendra yang menyatakan perlunya revisi terhadap UU Penodaan Agama, baik dalam lingkup formil perundang-undangan maupun secara substansi agar memiliki unsur-unsur materiil yang lebih diperjelas sehingga tidak menimbulkan kesalahan penafsiran dalam praktik.

Setelah menyatakan sikap yang tidak secara tegas mendorong adanya revisi tersebut, MK kemudian berlindung dibalik kewenangan yang dimiliki, dengan menyatakan bahwa MK tidak memiliki kewenangan untuk melakukan perbaikan redaksional dan cakupan isi, melainkan hanya boleh menyatakan apakah sebuah UU yang diujimaterikan itu konstitusional atau tidak konstitusional. Karena seluruh isi UU Pencegahan Penodaan Agama dianggap konstitusional, maka MK tidak dapat mengubah atau membatalkannya. Untuk memperbaiki agar lebih sempurna menjadi kewenangan pembentuk undangundang untuk melakukannya melalui proses legislasi yang normal. ${ }^{16}$

Argumen normatif MK tersebut memang tidak keliru, tetapi MK sebenarnya bisa lebih progresif sebagaimana dilakukan ketika memutuskan sejumlah judicial review (lihat catatan kaki no. 4). Dengan tetap berada dalam posisi sebagai negative legislator MK sebenarnya bisa sedikit beranjak dengan memberikan guidance dan memberi pernyataan yang kuat bahwa UU Penodaan Agama mengandung sejumlah masalah dan harus direvisi dalam bagian-bagian tertentu. Sayangnya, hal itu tidak dilakukan MK, sehingga sulit dikatakan MK mendorong adanya revisi UU yang disusun zaman orde lama ini. Bahkan hal yang tampak jelas dari amar putusan adalah penegasan bahwa UU Penodaan Agama adalah konstitusional, tidak ada masalah baik secara formil maupun

\footnotetext{
${ }^{15}$ Bandingkan dengan paper yang ditulis Zainal Abidin Bagir, "Di Manakah Jalan Tengah?: Beberapa Catat an atas Putusan MK mengenai UU Penodaan Agama," tulisan dipresentsikan dalam pertemuan aktifis NGO yang difasilitasi HIVOS di Hotel Grand Kemang Jakarta, 16 Juni 2010.

${ }^{16}$ Amar Putusan, 304-305.
} 
materiil, masih relevan, bisa melindungi ketentraman beragama, sehingga harus dipertahankan. $^{17}$

Kalau toh ada kelompok yang merasa terdiskriminasi atau diperlakukan tidak adil melalui UU tersebut, hal itu bukan persoalan norma hukum yang ada dalam UU Penodaan Agama yang bertentangan dengan konstitusi, tapi lebih karena kesalahan penerapan norma dalam hukum administrasi. ${ }^{18}$ Di sini MK telah mengabaikan berbagai fakta bahwa UU ini telah digunakan bukan saja untuk membatasi ekspresi keberagamaan (forum eksternum) tapi juga untuk membatasi hak privat yang masuk dalam kategori forum internum. MK dengan ringan akan mengatakan, hal itu bukan persoalan norma hukum, tapi problem implementasi. MK memang memberi argumentasi yang kuat bahwa praktik diskriminasi merupakan kekeliruan, tapi pada saat yang sama MK menolak jika UU Penodaan Agama dikaitkan atau dituduh diskriminatif. Jika ada yang menjadikan UU Penodaan Agama sebagai landasan kebijakan diskriminatif, hal itu merupakan kesalahan implementasi, bukan persoalan UU-nya itu sendiri.

Jika cara berpikir ini diikuti, maka kita bisa bertanya: bagaimana kita bisa memastikan bahwa sebuah UU itu benar jika dalam praktiknya justru menimbulkan banyak masalah? Bagaimana sebuah UU dikatakan tidak diskriminatif tapi dijadikan landasan melakukan diskriminasi? Pada titik inilah sebenarnya MK, sekali lagi, bisa lebih progresif sebagaimana dilakukan dalam kasus-kasus lain, tidak hanya berhenti pada argumen normatif.

Mengapa MK lebih memilih untuk mendukung argumentasi kelompok pertama, yang ingin mempertahankan UU Pencegahan Penodaan Agama dan tidak memberi dorongan kuat untuk melakukan revisi? Pertanyaan tersebut agaknya bisa dipahami dengan melihat kutipan sebagai berikut:

“...Jika hal tersebut (penodaan agama, pen.) tidak diatur, maka dikhawatirkan dapat menimbulkan benturan serta konflik horizontal, dapat menimbulkan keresahan, perpecahan, dan permusuhan dalam masyarakat...". ${ }^{19}$

Ketakutan (tepatnya, ancaman yang diimajinasikan) akan terjadi anarkisme sosial senantiasa dikemukakan berbagai kalangan yang menolak pencabutan UU Penodaan Agama. Mereka selalu mengatakan, jika UU ini

${ }^{17}$ Amar Putusan, 312

${ }^{18}$ Lihat Amar Putusan h. 305-306. Terkait dengan penganut aliran kepercayaan yang merasa terdiskriminasi akibat UU Penodaan Agama, MK menyatakan, masyarakat penganut kepercayaan mempunyai hak dan kewajiban yang sama dalam meyakini kepercayaannya sesuai dengan jaminan dalam konstitusi. Adapun diskriminasi yang dialami oleh masyarakat penganut kepercayaan bukan merupakan permasalahan pertentangan UU Pencegahan Penodaan Agama dengan UUD 1945, tapi lebih pada kesalahan penerapan norma hukum administrasi.

${ }^{19}$ Amar Putusan, 287. 
dicabut, maka orang akan dengan seenaknya melakukan penodaan agama, akan terjadi kekosongan hukum dan sebagainya. Di pihak lain, pendapat kalangan yang menghendaki UU Penodaan Agama dicabut justru karena UU inilah yang secara nyata telah melahirkan ketegangan sosial. Dua cara pandang tersebut jelas bertolak belakang. Di sini, MK lagi-lagi tidak mencari "jalan tengah" tapi justru meng-amini ketakutan-ketakutan akan adanya konflik horizontal, sebagaimana dikemukakan kelompok pendukung UU Penodaan Agama. Karena itu, tidak salah jika putusan MK terkait UU Penodaan Agama berada dalam bayang-bayang ketakutan ancaman konflik horizontal.

Upaya melakukan "jalan tengah" yang lebih masuk akal sebenarnya lebih tampak dari pendapat Hakim Konstitusi Harjono yang memberi alasan berbeda (concuring opinion), meskipun pendapat ini tidak menjadi keput usan final MK. Kalau saja MK mengambil pendapat Hakim Harjono, maka MK bisa dikatakan berhasil menempuh "jalan tengah" sebagaimana yang Mahkamah inginkan. Dalam kaitan ini, penulis merasa perlu untuk mengemukakan secara agak komprehensif pendapat Hakim Harjono.

Menurut Hakim Harjono, rumusan pasal $1^{20}$ UU Penodaan Agama yang diajukan judicial review memang mengandung sejumlah kelemahan sehingga pasal 1 UU tersebut perlu direvisi oleh lembaga pembuat undang-undang. Memang Hakim Harjono masih menyimpan kekhawatiran, jika UU a quo dicabut maka akan terdapat ke-vakum-an hukum yang hal itu dapat menimbulkan akibat sosial yg luas. Namun di sisi lain, Hakim Harjono juga mengakui bahwa akibat itu bisa diatasi dengan aturan hukum yang ada, meski hal itu memerlukan social cost yang tinggi.

Argumen Hakim Harjono bertolak dari pandangan bahwa dalam kaitan dengan UU Pencegahan Penodaan Agama dan UUD 1945 yang telah mengalami perubahan, ada dua hal yang harus diperhatikan dengan seksama, yaitu perlindungan agama di satu pihak, dan hak kebebasan meyakini sebuah kepercayaan di pihak lain. Hubungan antara dua unsur tersebut harus disatukan dalam formula yang tidak menegasikan satu unsur dengan unsur lainnya. Dalam pandangan Hakim Harjono, penerapan UU a quo secara harfiyah dapat menimbulkan ketidakseimbangan, sehingga merusak keinginan untuk mencari keseimbangan dua unsur tersebut. Untuk menjelaskan kerancuan punyi pasal 1, Hakim Harjono membuat peragaan kasus. Ada seseorang yang dengan keyakinannya sengaja membuat penafsiran tentang agama lain berdasar dalil-

\footnotetext{
${ }^{20}$ Pasal 1 UU Pencegahan Penodaan Agama berbunyi: "Setiap orang dilarang dengan sengaja di muka umum menceritakan, menganjurkan atau mengusahakan dukungan umum untuk melakukan penafsiran tentang sesuatu agama yang dianut di Indonesia atau melakukan kegiatan-kegiatan keagamaan yang menyerupai kegiatan-kegiatan agama itu, penafsiran dan kegiatan mana menyimpang dari pokok-pokok ajaran dari agama itu."
} 
dalil agama yang dia yakini, namun penafsiran tersebut berbeda dengan pokokpokok ajaran agama lain tersebut.

Secara harfiyah, orang tersebut telah memenuhi unsur untuk disebut melakukan penodaan agama, karena ia telah melakukan penafsiran agama yang dianut di Indonesia yang penafsirannya menyimpang dari pokok-pokok ajaran agama tersebut. Untuk memenuhi unsur delik penodaan agama secara lengkap, maka hal itu harus dinyatakan di muka umum. Apa yang dimaksud "di muka umum?" Dalam penjelasan pasal 1 UU a qua, "di muka umum" dimaksudkan apa yang lazim diartikan kata-kata itu dalam Kitab Undang-undang Hukum Pidana (KUHP). Dengan demikian, yang dimaksud "di muka umum" adalah tempat dimana terdapat lebih dari satu orang, yang artinya terdapat orang lain. Masalahnya, apakah pasal ini memang dimaksudkan untuk melarang orang bicara tentang agama lain di depan umatnya sendiri untuk menafsirkan agama lain yang berbeda dengan pokok-pokok ajaran agama lain yang ditafsirkan? Jika ada yang menjawab "bukan", dari rumusan mana jawaban itu didasarkan?

Dari ilustrasi tersebut, Hakim Harjono menyakini bahwa pasal 1 UU a quo dari sudut redaksional mengandung ketidakjelasan sehingga tidak memenuhi syarat bahwa perumusan undang-undang tindak pidana haruslah jelas (lex certa). Apabila rumusan pasal 1 UU a quo tidak dimaksudkan untuk melarang ceramah agama yang mengandung tafsir terhadap agama lain yang berbeda dengan pokok-pokok ajaran agama lain tersebut yang ceramah dilakukan hanya hadapan penganut agama dari penceramah, Hakim Harjono berpendapat, maksud tersebut dapat dilakukan dengan cara memberi batasan tentang unsur di muka umum. Hal itu bisa dilakukan dengan tidak memasukkan pengertian di muka umum apabila perbuatan menceritakan tersebut meskipun di hadapan banyak orang namun di tempat yang hanya dimaksudkan untuk dihadiri oleh penganut agama yang sama dengan agama penceramah atau di tempat yang dimaksudkan demikian. Hal ini menunjukkan bahwa ada kelemahan yang harus diakui dalam pasal 1 UU Penodaan Agama. Karena itu, Hakim Harjono, menyarankan perlunya melakukan revisi oleh lembaga pembuat UU.

Hakim Harjono memang tidak menyarankan untuk mencabut atau membatalkan UU a quo karena kekhawatiran adanya ke-vakum-an hukum dan kekacauan sosial. Ia berpendapat, dengan dasar asas kemanfaatan sambil menunggu penyempurnaan yang dilakukan oleh pembuat UU, untuk sementara waktu UU a quo perlu dipertahankan. Dalam beberapa putusannya Mahkamah dapat menetapkan status suatu bagian UU sebagai conditionally constitutional dengan cara memberikan syarat keberlakukannya. Namun, menurutnya, terhadap pasal 1 UU a quo hal demikian tidak dapat dilakukan karena syarat tersebut akan sangat umum sifatnya, padahal penerapan pasal tersebut berlaku untuk semua agama yang masing-masing mempunyai karakteristik berbeda 
antara satu dengan yang lain. Untuk mengatasi hal demikian, sebenarnya dapat dilakukan oleh hakim yang memutus perkara konkret dengan mempertimbangkan perubahan yang ada untuk menyelaraskan dua unsur tersebut di atas.

Pendapat Hakim Konstitusi Harjono ini, dalam pandangan penulis lebih dapat disebut sebagai "jalan tengah". Di samping secara eksplisit dia menyebut adanya kelemahan dalam UU Penodaan Agama, dia juga lebih tegas untuk mendorong DPR sebagai lembaga pembuat undang-undang melakukan revisi. Hal ini berbeda dengan keputusan yang diambil Mahkamah, yang cenderung menafikan problem yang ada dalam UU yang diajukan judicial review ini.

Pendapat sejumlah ahli, termasuk ahli yang secara khusus diundang MK, yang memandang perlunya melakukan revisi terhadap UU Penodaan Agama sebenarnya cukup kuat terlontar sebagai bagian dari fakta persidangan. Yusril Ihza Mahendra, misalnya, setelah menyatakan bahwa secara formil maupun materiil UU itu tidak berlawanan dengan konstitusi, ia menyatakan juga bahwa "dari segi bentuk pengaturan, rumusan, kaidah-kaidah hukumnya perlu disempurnakan." ${ }^{21}$ Ia juga menunjukkan adanya kekacauan (berdasarkan UU No. 10/2004) dalam penjelasan pasal 1 dan pasal 2, karena penjelasan itu mengandung norma, yang tidak ada dalam pasal. Persoalan lain adalah penerapan UU itu yang "tidak ideal," meskipun hal itu terjadi hampir pada semua ketentuan pidana di Indonesia. Meskipun penerapan yang tidak ideal tersebut tidak menggugurkan norma dalam teks, namun hal itu penting untuk mendapat perhatian, karena pasti ada sesuatu yang keliru. Karena itu Yusril pada akhirnya menyarankan DPR, Presiden dan Kementrian terkait untuk menyempurnakan UU itu, dengan melibatkan seluruh pihak yang berkepentingan, sehingga hal-hal yang dirasakan kurang sempurna dapat disempurnakan bersama.

Ahli-ahli lain juga menyatakan adanya problem serupa. Ahli EOS Hiariej menyebutkan bahwa UU Penodaan Agama sering digunakan untuk menghakimi pemikiran dan keyakinan seseorang, tidak semata-mata soal ekspresi atas pikiran dan keyakinan. Meski hal ini tidak bisa dijadikan argumen untuk membatalkan norma dalam UU Penodaan Agama, namun hal ini menunjukkan bahwa UU ini problematis. Azyumardi Azra juga menegaskan hal yang sama, dimana perlu adanya revisi untuk menghindari ambiguitas dan ekses-ekses negatif yang ditimbulkan dari UU Penodaan Agama. Sejumlah ahli lain juga menyatakan hal yang kurang lebih sama untuk mendorong perlunya penyempurnaan karena UU ini telah menciptakan kecemasan terus menerus. ${ }^{22}$

\footnotetext{
${ }^{21}$ Lihat Amar Putusan MK, 222.

${ }^{22}$ Lihat Amar Putusan MK, 210-224.
} 


\section{"Jalan Tengah": Antara Negara Islam dan Negara Sekuler}

Aspek "jalan tengah" kedua yang ingin ditunjukkan dalam putusan MK ini adalah persoalan pertarungan lama dalam sejarah pendirian negara Indonesia sejak masa-masa awal kemerdekaan, yaitu pertarungan ideologi negara Islam dan negara sekuler. ${ }^{23}$ Dalam kaitan ini, putusan MK ini tidak semata-mata bicara soal hukum dan konstitusi, tapi sudah merambat ke persoalan politik, bukan politik kekuasaan, tapi politik kenegaraan. Persoalan ini sebenarnya tidak ada kaitan langsung dengan UU Penodaan Agama, tapi MK tampaknya mempunyai kepentingan untuk mengangkat tema ini hanya untuk menunjukkan bahwa negara mempunyai legitimasi untuk mengintervensi keyakinan keagamaan warganya.

Sebagaimana dimaklumi, dalam sejarah pendirian negara Indonesia, para founding fathers kita pernah berdebat sengit mengenai bentuk negara. Menurut para ahli sejarah, mereka terbagi dalam dua kelompok besar, yaitu nasionalis Islam, yang menghendaki agar Islam menjadi dasar Negara, dan dan nasionalis sekuler yang menghendaki Indonesia sebagai negara nasional dengan Pancasila sebagai dasar negara. ${ }^{24}$ Dua arus tersebut ditengahi dengan adanya gagasan yang dikenal sebagai "Piagam Jakarta", yang menambahkan tujuh kata setelah Ketuhanan Yang Maha Esa, yaitu: "dan kewajiban menjalankan syariat Islam bagi pemeluk-pemeluknya". Tujuh kata Piagam Jakarta ini pun akhirnya dihilangkan karena adanya penolakan dari tokoh Indonesia timur yang mayoritas beragama Kristiani. Rumusan Piagam Jakarta dianggap telah mengingkari prinsip kesamaan warga negara karena Islam mempunyai posisi lebih tinggi disbanding agama-agama lain.

Meskipun penghapusan tujuh kata Piagam Jakarta termasuk bagian dari sejarah yang agak gelap, namun tujuh kata tersebut memang telah menempatkan Islam dalam posisi yang lebih istimewa dibanding agama-agama lain. Hal ini bisa menjadi bumerang dalam menapaki kehidupan ke depan. Karena itu, demi menjaga integrasi bangsa, tokoh-tokoh Islam kala itu merelakan penghapusan tujuh kata tersebut. Dari sejarah itulah, muncul adagium untuk menggambarkan negara Indonesia: "bukan negara sekuler dan bukan negara agama". Dikatakan bukan negara sekuler karena negara Indonesia tidak menafikan peran agama dalam kehidupan berbangsa; dan tidak dikatakan negara agama karena negara Indonesia tidak didasarkan pada keyakinan agama tertentu, yang lazim disebut sebagai negara teokrasi. Bagi kalangan yang tidak

\footnotetext{
${ }^{23}$ Perdebatan lebih jauh mengenai pergumulan ini, baca Bahtiar Effendy, Islam dan Negara, Transformasi Pemikiran dan Praktik Politik Islam di Indonesia (Jakarta: Paramadina, 1999).

${ }^{24}$ Penjelasan lebih lanjut mengenai perdebatan ini, lihat Bahtiar Effendy, Islam dan Negara.
} 
memahami pergumulan pembentukan negara Indonesia pasti sulit memahami adagium tersebut.

Dalam amar putusannya, MK tampak sekali berupaya untuk meniti jalan tengah tersebut yang diawali dengan membangun argumen mengenai relasi agama dan negara. Titik tolak argumentasi MK mengenai relasi agama dan negara adalah Pancasila. Pancasila sebagai dasar negara harus diterima seluruh warga negara, baik secara individu maupun kolektif. Sila "Ketuhanan Yang Maha Esa" sebagai sila pertama dari Pancasila memberikan landasan yang kuat bahwa Indonesia Negara ber-Tuhan. Hal ini kemudian dituangkan dalam konstitusi, UUD 1945 Pasal (29): Negara berdasar atas Ketuhanan Yang Maha Esa. Dengan demikian, sejak awal Indonesia adalah negara ber-Tuhan, bukan saja warganya, tapi negaranya pun harus ber-Tuhan. Karena itu, orang yang mengaku tidak ber-Tuhan tidak punya hak hidup di Indonesia. Domain keyakinan terhadap Tuhan Yang Maha Esa adalah domain forum internum yang merupakan konsekuensi penerimaan Pancasila sebagai dasar negara. Dalam pandangan MK, Sila Ketuhanan Yang Maha Esa menurunkan undang-undang yang mewajibkan setiap penyelenggara pendidikan mengajarkan agama sebagai suatu mata pelajaran, sesuai dengan agama masing-masing. Mengajarkan agama berarti mengajarkan kebenaran keyakinan agama kepada peserta didik, yaitu siswa dan mahasiswa. Dengan demikian, pengajaran pendidikan agama di sekolah (negeri) bukan dilihat sebagai "intervensi", sebaliknya sebagai "fasilitasi” negara terhadap kebutuhan masyarakat untuk mempelajari ajaran agama.

Namun, pada bagian berikutnya, ada kutipan yang agak aneh, karena MK mengutip dari Majalah Media Dakwah dan Suara Hidayatullah, dua majalah yang lebih berhalauan "Piagam Jakarta". Pada bagian itu disebutkan:

"Di Amerika mengajarkan agama di sekolah-sekolah negeri adalah inkonstitusional, hal ini karena adanya kebebasan beragama dan kebebasan untuk tidak beragama. Keyakinan beragama atau tidak beragama merupakan forum internum bagi setiap warga negara yang tidak boleh diintervensi oleh Negara." 25

Kutipan tersebut, bukan saja menunjukkan cara pandang yang layak dipertanyakan, tapi juga mengandung simplifikasi yang berlebihan. Mengatakan bahwa di AS dilarang mengajarkan agama di sekolah-sekolah negeri karena adanya kebebasan beragama jelas merupakan pernyataan yang serampangan. Kutipan tersebut bisa ditafsirkan, karena di Indonesia tidak ada kebebasan beragama dan tidak ada kebebasan untuk tidak ber-Tuhan, maka

\footnotetext{
${ }^{25}$ Amar Putusan MK, 273.
} 
agama harus diajarkan di sekolah. Cara pandang demikian tentu tidak bisa dipertanggungjawabkan.

Argumen MK sebenarnya masih bisa diterima, sejauh hal tersebut sebagai bentuk pelayanan Negara, bukan pemaksaan atas sebuah keyakinan kepada anak didik. Inilah yang dimaksud MK sebagai "perspektif ke-Indonesiaan" mengenai posisi agama yang membedakan dengan demokrasi Barat. Di Indonesia, agama bukan hanya dipeluk, tapi nilai-nilainya menjadi salah satu pembatas kebebasan asasi seseorang semata-mata untuk menghormati hak dan kebebasan orang lain. Sampai di sini ada argumen yang tidak runtut dari MK, kalau tidak dikatakan melompat.

Setelah menjelaskan bahwa nilai-nilai agama bisa digunakan untuk membatasi kebebasan seseorang, MK tidak memberi elaborasi apapun. MK justru menjelaskan hal yang sebaliknya, yaitu adanya semacam state favoritism, meskipun hal tersebut tidak selalu bisa disebut sebagai diskriminasi. Hal ini bisa dilihat dari pernyataan MK bahwa, "dalam tingkat politik kenegaraan, negara membentuk satu kementerian khusus yang membidangi urusan agama yaitu Kementerian Agama. Hari-hari besar keagamaan dihormati dalam praktik bernegara. Demikian pula hukum agama dalam hal ini syari'at Islam yang terkait dengan nikah, talak, rujuk, waris, hibah, wasiat, wakaf, ekonomi syari'ah, dan lain-lain telah menjadi hukum negara khususnya yang berlaku bagi pemeluk agama Islam". 26

Kutipan tersebut jelas bukan merupakan penjelasan adanya pembatasan kebebasan seseorang untuk menghormati hak dan kebebasan orang lain. Tapi justru menjelaskan bagaimana negara mengakomodasi tradisi dan hukum agama (Islam) menjadi bagian dari hukum negara. Barangkali MK mengangkat hal ini untuk menunjukkan bahwa Indonesia bukanlah negara yang secara tegas memisahkan antara urusan agama dan urusan politik, dan inilah "tipikal" Indonesia yang berbeda dari negara-negara demokrasi Barat. Secara tidak disadari, akomodasi seperti inilah yang sebenarnya dikehendaki "Piagam Jakarta" dimana umat Islam mempunyai hukum sendiri yang diberlakukan melalui negara. Melalui Amar Putusan ini secara tidak disadari sebenarnya MK sedang melegitimasi ideologi politik "Piagam Jakarta".

Sebagai realitas politik, akomodasi tradisi dan syariah Islam dalam politik Indonesia merupakan konsekuensi dari politik "Ketuhanan Yang Maha Esa" sebagaimana ditekankan MK. Pertanyaannya, sejauhmana akomodasi tradisi dan syariah Islam bisa diakomodasi dalam struktur kenegaraan Indonesia? Apakah hanya hukum keluarga, peradilan agama, zakat, wakaf, haji, dan hukum ekonomi (perbankan) Islam saja yang bisa diformalisasikan dalam hukum

${ }^{26}$ Lebih jauh lihat Amar Putusan MK, 275. 
nasional yang hanya berlaku bagi umat Islam? Batas akomodasi inilah yang lepas dari perhatian MK. Apakah, misalnya, kalau ada orang memperjuangkan hukum pidana Islam menjadi hukum nasional yang diimplementasikan melalui peradilan agama dan hanya berlaku bagi umat Islam, masih bisa dianggap sebagai bentuk akomodasi untuk menegaskan politik "Ketuhanan Yang Esa".

Inilah problem krusial hubungan agama dan negara yang tidak tuntas diulas MK. MK mengulas persoalan posisi agama dalam negara justru hanya untuk menegaskan bahwa negara mempunyai kewenangan untuk mengintervensi beberapa segi kehidupan bergama, termasuk dengan mengkriminalisasi perbuatan-perbuatan yang dikategorikan sebagai penodaan agama. Inilah yang dimaksud MK dalam kutipan berikut:

"Pasal-pasal penodaan agama tidak semata-mata dilihat dari aspek yuridis saja melainkan juga aspek filosofisnya yang menempatkan kebebasan beragama dalam perspektif keindonesiaan, sehingga praktik keberagamaan yang terjadi di Indonesia adalah berbeda dengan praktik keberagamaan di negara lain yang tidak dapat disamakan dengan Indonesia. Terlebih lagi, aspek preventif dari suatu negara menjadi pertimbangan utama dalam suatu masyarakat yang heterogen."27

Legitimasi delik penodaan agama tersebut berdiri diatas prinsip "Ketuhanan Yang Maha Esa" yang menjadi poros dari seluruh sistem hukum di Indonesia. Dalam pandangan MK, prinsip hukum Indonesia harus dilihat dengan cara pandang UUD 1945, yaitu negara hukum yang menempatkan prinsip Ketuhanan Yang Maha Esa sebagai prinsip utama, serta nilai-nilai agama yang melandasi gerak kehidupan bangsa dan negara, bukan negara yang memisahkan hubungan antara agama dan negara (separation of state and religion), serta tidak semata-mata berpegang pada prinsip individualisme maupun prinsip komunalisme.

\section{Antara Kebebasan Beragama dan Penodaan Agama}

Salah satu argumen MK dalam merumuskan keputusan dalam judicial review ini adalah, UU No. 1/PNPS/1965 tidak ada hubungan dengan kebebasan beragama, tapi hanya terkait dengan penodaan agama. Berikut ini penulis akan mengutip sejumlah pernyataan yang menjadi pertimbangannya MK dalam mengambil keputusan. Sejumlah pernyataan tersebut antara lain:

"Menimbang bahwa menurut Mahkamah, UU Pencegahan Penodaan

Agama tidak menentukan pembatasan kebebasan beragama, akan tetapi pembatasan untuk mengeluarkan perasaan atau melakukan

\footnotetext{
${ }^{27}$ Amar Putusan MK, 274.
} 
perbuatan yang bersifat permusuhan, penyalahgunaan atau penodaan terhadap suatu agama serta pembatasan untuk melakukan penafsiran atau kegiatan yang menyimpang dari pokok-pokok ajaran agama yang dianut di Indonesia." 28

Pada bagian lain, amar putusan MK juga menyatakan:

"Menimbang bahwa Mahkamah berpendapat UU Pencegahan Penodaan Agama masih diperlukan dan sama sekali tidak bertentangan dengan perlindungan HAM sebagaimana diatur di dalam UUD 1945. Dalam kaitan ini, Mahkamah sependapat dengan Ahli Ketua Umum PBNU KH Hasyim Muzadi yang menyatakan; pertama, UU Pencegahan Penodaan Agama bukan Undang-Undang tentang kebebasan beragama sebagai hak asasi manusia melainkan UndangUndang tentang larangan penodaan terhadap agama. Kedua, UU Pencegahan Penodaan Agama lebih memberi wadah atau bersifat antisipatif terhadap kemungkinan terjadinya tindakan anarkis apabila ada penganut suatu agama yang merasa agamanya dinodai. Dengan adanya UU Pencegahan Penodaan Agama, jika masalah seperti itu timbul maka dapat diselesaikan melalui hukum yang sudah ada (UU Pencegahan Penodaan Agama). Di samping itu, substansi Pasal 1 UU Pencegahan Penodaan Agama bukan dimaksudkan untuk mengekang kebebasan beragama, melainkan untuk memberikan rambu-rambu tentang pencegahan penyalahgunaan dan/atau penodaan agama. Penodaan agama atau penghinaan terhadap agama (blasphemy atau defamation of religion) juga merupakan bentuk kejahatan yang dilarang oleh banyak negara di dunia. Secara substantif Pasal 1 UU Pencegahan Penodaan Agama tidak dapat serta merta diartikan sebagai bentuk dari pengekangan forum externum terhadap forum internum seseorang atas kebebasan beragama" ${ }^{29}$

Hal tersebut ditegaskan ulang pada bagian berikutnya:

"Bahwa permohonan pemohon telah keliru memahami pasal $1 \mathrm{UU}$ Pencegahan Penodaan Agama sebagai sebuah pembatasan atas kebebasan beragama. Mahkamah berpendapat bahwa Pasal 1 UU Pencegahan Penodaan Agama adalah bagian tidak terpisahkan dari maksud perlindungan terhadap hak beragama warga masyarakat Indonesia sebagaimana yang terkandung dalam inti UU Pencegahan

${ }_{28}^{28}$ Amar Putusan MK, 287.

${ }^{29}$ Amar Putusan MK, 294. 
Penodaan Agama yakni untuk mencegah penyalahgunaan dan penodaan agama demi kerukunan hidup berbangsa dan bernegara. Oleh sebab itu, Mahkamah berpendapat bahwa Pasal 1 UU Pencegahan Penodaan Agama sejalan dengan amanat UUD 1945 yakni untuk mewujudkan kehidupan berbangsa dan bernegara yang lebih baik (the best life possible) dan karenanya dalil-dalil Pemohon harus dikesampingkan." ${ }^{30}$

Dari kutipan tersebut, ada catatan penting untuk mendapat perhatian. Pertama, Dengan mengamini pendapat ahli, KH. Hasyim Muzadi, Mahkamah yakin betul bahwa UU Pencegahan Penodaan Agama tidak ada hubungan dengan kebebasan beragama. Alih-alih membatasi kebebasan beragama, UU Pencegahan Penodaan Agama justru untuk melindungi kebebasan beragama. Benarkah demikian? Penulis tidak sepenuhnya setuju dengan cara pandang demikian. Baik langsung maupun tidak langsung, baik secara teoritikkonseptual maupun dari segi praktek dalam pengadilan, delik penodaan agama tidak dapat dilepaskan dari kebebasan beragama.

Dalam kaitan ini ada semacam kontradiksi dalam logika Mahkamah. Di satu sisi, Mahkamah menolak mengkaitkan UU Pencegahan Penodaan Agama dengan kebebasan beragama, namun di sisi lain Mahkamah mengajukan argumen bahwa kebebasan beragama tidaklah mutlak, dan UU ini merupakan bentuk pembatasan terhadap kebebasan beragama. Demikian juga dalam berbagai bagian, Mahkamah senantiasa menyebut berbagai teori kebebasan beragama.

Kedua, salah satu aspek dari argumen MK dalam persoalan penodaan agama adalah persoalan individualisme dan komunalisme. Kebebasan beragama merupakan konsep yang lebih dekat dengan hak individu, sedang konsep penodaan agama diarahkan untuk melindungi "hak komunal". Dengan demikian, tidak mengkaitkan persoalan penodaan agama dengan kebebasan beragama merupakan cara mengelak dari perbincangan yang lebih serius. UU Pencegahan Penodaan Agama merupakan UU yang memang dibuat untuk membatasi kebebasan seseorang, bukan saja dalam menyangkut cara mengekspresikan keyakinan (forum externum), tapi juga terkait dengan keyakinan dan penafsiran seseorang atas agama (forum intenum). Karena itu, yang tidak mutlak bukan saya forum eksternum, tapi hal-hal yang masuk kategori forum internum, seperti soal penafsiran agama, pun tidak mutlak. Simaklah kutipan berikut:

\footnotetext{
${ }^{30}$ Amar Putusan MK, 295.
} 
"Walaupun penafsiran keyakinan atas ajaran agama merupakan bagian dari kebebasan yang berada pada forum internum, namun penafsiran tersebut haruslah berkesesuaian dengan pokok-pokok ajaran agama melalui metodologi yang benar berdasarkan sumber ajaran agama yang bersangkutan yaitu kitab suci masing-masing, sehingga kebebasan melakukan penafsiran terhadap suatu agama tidak bersifat mutlak atau absolut. Tafsir yang tidak berdasarkan pada metodologi yang umum diakui oleh para penganut agama serta tidak berdasarkan sumber kitab suci yang bersangkutan akan menimbulkan reaksi yang mengancam keamanan dan ketertiban umum apabila dikemukakan atau dilaksanakan di muka umum. Dalam hal demikianlah menurut Mahkamah pembatasan dapat dilakukan".

MK secara eksplisit mengakui bahwa penafsiran keyakinan atas ajaran agama merupakan kebebasan yang berada dalam wilayah forum internum. Namun, demi kepentingan komunal dan politik "Ketuhanan Yang Maha Esa" maka forum internum pun bisa dibatasi. Hal ini berbeda dengan doktrin HAM dan kebebasan beragama internasional yang melarang intervensi terhadap forum internum. Pada wilayah ini, yang perlu dilakukan negara adalah memberi perlindungan agar hak-hak tersebut tidak diganggu orang lain. Konsep inilah yang disebut negative rights, yaitu kebebasan dalam bentuknya yang negatif, yang terdiri dari unsur "bebas untuk" melakukan berbagai hal yang bisa membuat manusia menjadi manusia yang bebas. Hukum moralitas atau nilainilai sosial yang mengatur tentang larangan melakukan intervensi mengandung unsur kebebasan negatif. Aturan tersebut ditujukan untuk melindungi hak seseorang dari semua bentuk intervensi yang dapat mengganggu kebebasannya. $^{32}$

Larangan melakukan prosiletisme (penyebaran agama secara tidak patut) dan penghujatan agama sebenarnya berada dalam konteks ini. Kadang-kadang dalam penyebaran agama dilakukan dengan mengganggu kebebasan orang lain, sehingga negara perlu melakukan intervensi dalam bentuk perlindungan kepada pemeluk agama. Demikian juga larangan penghujatan agama dimaksudkan untuk melindungi perasaan keagamaan individu dari kemungkinan dilukai orang lain. Dengan menghukum proselitisme, sebenarnya negara melakukan

\footnotetext{
${ }^{31}$ Amar Putusan MK, 288-289.

${ }^{32}$ Berbeda dengan konsep negative rights adalah positive rights, atau kebebasan positif. Kebebasan dalam bentuknya yang positif menekankan pada perlunya intervensi Negara untuk memastikan terwujudnya sebuah bentuk kebebasan yang menentukan seseorang untuk bisa mengatur bentuk-bentuk kehidupan manusia yang diinginkan. Jika tidak dilakukan intervensi, justru kebebasan itu akan terancam. Lebih jauh lihat Al-Hanif, Hukum dan Kebebasan Beragama di Indonesia (Yogyakarta: Leksbang Grafika, 2010), 90-91.
} 
intervensi terhadap kebebasan individu dalam memanifestasikan agamanya demi melindungi kebebasan keagamaan orang lain untuk tidak berpindah agama. Demikian juga, pemberian hukuman pada pelaku penghujatan agama, merupakan bentuk intervensi negara terhadap kebebasan berekspresi demi melindungi perasaan keagamaan orang lain. ${ }^{33}$

Ketiga, konsep penodaan agama dikacaukan dengan penyataan kebencian (hatred speech). Untuk menghindari kesalahpahaman, perlu dirumuskan bahwa penodaan agama hanya terkait dengan hujatan dan pernyataan kebencian, sehingga aspek penafsiran keyakinan agama dikeluarkan dari perbincangan persoalan penodaan agama. Artinya, seseorang tidak bisa dituduh melakukan penodaan agama hanya karena persoalan penafsiran keagamaan, meskipun penafsiran tersebut berbeda, bahkan menyimpang dari pemahaman kebanyakan orang. Sayangnya, hal ini tidak ditegaskan MK, bahkan MK meligitimasi adanya delik penodaan agama yang terkait dengan tafsir keagamaan. Hal inilah yang seharusnya menjadi sasaran revisi UU Penodaan Agama. Pembatasan kebebasan beragama hanya terkait dengan pembatasan untuk mengeluarkan perasaan atau melakukan perbuatan yang bersifat permusuhan, pelecehan dan terhadap simbol-simbol suatu agama.

\section{Penutup}

Meskipun Keputusan Mahkamah Konstitusi merupakan keputusan awal dan akhir sehingga tidak ada upaya hukum lain, tetapi keputusan tersebut tetap bisa dinilai oleh publik. Eksaminasi publik semacam ini memang tidak bisa merubah keputusan hukum, namun paling tidak bisa memberi sudut pandang tertentu atas putusan pengadilan. Hal ini penting untuk memberi pendidikan kepada masyarakat bahwa putusan pengadilan, termasuk putusan MK yang dianggap cukup kredibel, tetap saja terdapat ruang kritik. Keputusan pengadilan bukan semata sebagai dokumen hukum, tapi juga merupakan sumber ilmu pengetahuan yang bisa diuji dari sudut akademik.

Dalam kaitan ini, ada beberapa hal yang bisa digarisbawahi. Pertama, ruang publik yang di buka Mahkamah Konstitusi untuk membicarakan persoalan yang sangat krusial dalam sejarah kehidupan bangsa Indonesia menyangkut relasi agama dan Negara, patut diberi apresiasi. Inilah forum konstitusional pertama setelah sekian lama permbicaraan mengenai relasi agama dan Negara nyaris tertutup, atau paling-paling disebut sambil lalu dalam ruang-ruang seminar dan dialog televisi. Melalui forum di MK, semua orang

${ }^{33}$ David Llewellyn and H. Victor Conde, "Freedom of Religion or Belief under International Humanitarian Law", dalam Tore Lindolm, W. Cole Durham (editor), Facilitating Freedom of Religion or Belief: A Deskbook (Oslo: The Norwegian Centre for Human Rights, 2004), 160-163. 
dari berbagai aliran pemikiran diberi ruang yang sama untuk kembali menilai persoalan krusial ini. Judicial review ini bukan semata-mata ruang pengadilan, tapi juga sekaligus ruang kontestasi intelektual yang luar biasa. Meski ada tekanan-tekanan kecil di luar sidang MK, tetapi hal tersebut tidak mempengaruhi jalannya persidangan.

Kedua, secara substansial, sebenarnya MK mengakui adanya persoalan dalam UU Penodaan Agama, baik menyangkut substansi hukum maupun implementasinya. Secara substansi, meskipun UU yang direview ini terkait dengan penodaan agama, namun di dalamnya juga menjadi sumber diskriminasi bagi penganut agama dan keyakinan di luar enam agama yang dianggap "resmi". Dalam impelementasinya, MK juga mengakui bahwa UU Penodaan agama sering digunakan secara tidak tepat. Namun, karena MK hanya menguji norma hukumnya, maka soal implementasi ini tidak bisa menjadi dalil untuk membatalkan UU Penodaan Agama.

Ketiga, kalangan legislatif semestinya segera menangkap pesan dalam putusan MK untuk memperbaiki UU Penodaan Agama. Meski delik penodaan agama tidak bisa dihilangkan, namun adanya UU yang memastikan bahwa UU ini tidak eksesif dan bisa diterapkan secara semena-mena menjadi hal yang sangat penting. Diakui atau tidak, UU Penodaan Agama sering diimplementasikan dengan melanggar hak asasi manusia, terutama terkait dengan hak kebebasan beragama dan berkeyakinan yang dijamin secara tegas dalam konstitusi.

\section{Daftar Pustaka}

Amar Put usan MK No. 140/PUU-VII/2009.

Arief, Barda Nawawi. Delik Agama dan Penghinaan Tuhan (Blasphemy) di Indonesia dan Perbandingan Berbagai Negara. Semarang: UNDIP Semarang, 2007.

Article XIX, Freedom of Expression and Offense, presentasi oleh Sarac Richani.

Bagir, Zainal Abidin. "Di Manakah Jalan Tengah?: Beberapa Catatan atas Putusan MK mengenai UU Penodaan Agama." Tulisan dipresentsikan dalam pertemuan aktifis NGO yang difasilitasi HIVOS di Hotel Grand Kemang Jakarta, 16 Juni 2010.

Bahtiar Effendy, Islam dan Negara, Transformasi Pemikiran dan Praktik Politik Islam di Indonesia. Jakarta: Paramadina, 1999.

Becket Found for Religious liberty Issues Brief, “Defamation of Religion”, July 2008 (Versi Publikasi).

Carly Carlberg, 'Freedom of Expression in Modern Age: An Obscure Blasphemy Statute and Its Effect on Bussiness Naming, "Rutger Journal of Law and Religion," Volume II (Fall 2009), Part I. 
Hanif, Al. Hukum dan Kebebasan Beragama di Indonesia. Yogyakarta: Leksbang Grafika, 2010.

Llewellyn, David dan H. Victor Conde. "Freedom of Religion or Belief under International Humanitarian Law." Dalam Tore Lindolm, W. Cole Durham (ed.), Facilitating Freedom of Religion or Belief: A Deskbook . Oslo: The Norwegian Centre for Human Rights, 2004.

Priestly, Brinton. Blasphemy and Law: A Comparative Study (2006), http://www.brentonpriestley.com/writing/blasphemy.htm.

Senoadji, Oemar. Hukum (Acara) Pidana dalam Prospeksi. Jakarta: Erlangga, 1976.

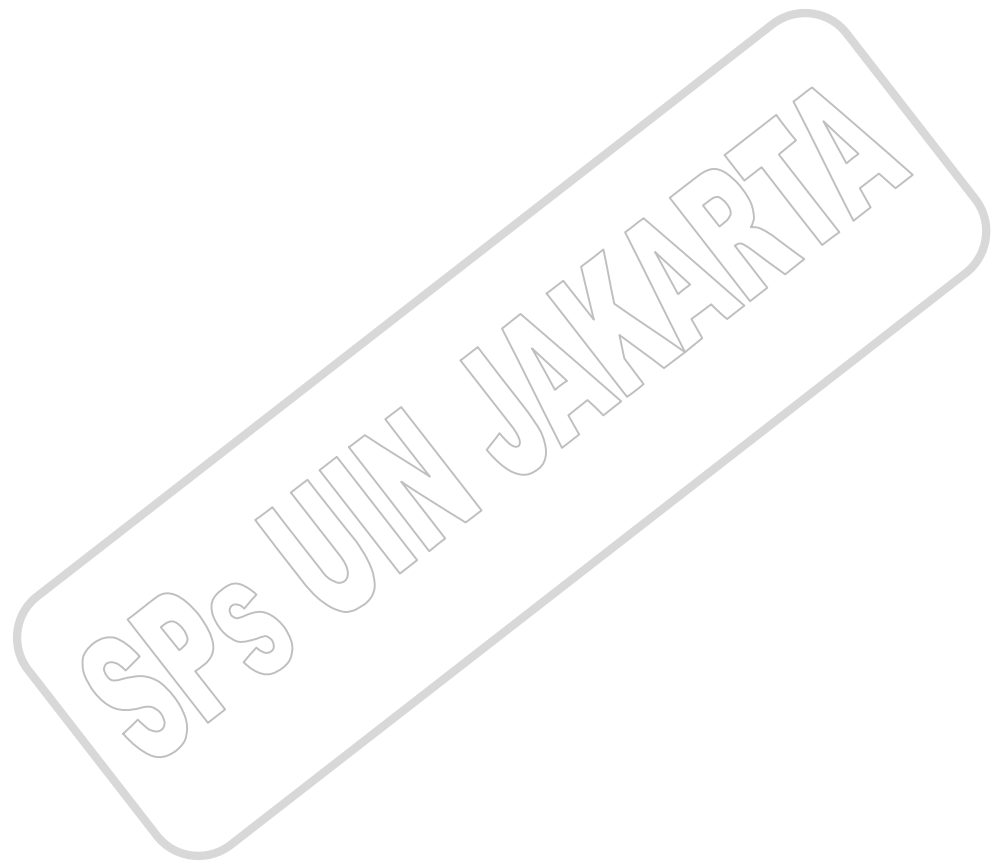

